\title{
Post-splenectomy Sepsis: A Review of the Literature
}

Faryal Tahir ${ }^{1}$, Jawad Ahmed ${ }^{1}$, Farheen Malik ${ }^{2}$

1. Internal Medicine, Dow University of Health Sciences, Karachi, PAK 2. Pediatrics, Dow University of Health Sciences, Karachi, PAK

Corresponding author: Jawad Ahmed, jawadahmedd13@gmail.com

\begin{abstract}
The spleen is an intraperitoneal organ that performs vital hematological and immunological functions. It maintains both innate and adaptive immunity and protects the body from microbial infections. The removal of the spleen as a treatment method was initiated from the early 1500s for traumatic injuries, even before the physiology of spleen was properly understood. Splenectomy has therapeutic effects in many conditions such as sickle cell anemia, thalassemia, idiopathic thrombocytopenic purpura (ITP), Hodgkin's disease, and lymphoma. However, it increases the risk of infections and, in some cases, can lead to a case of severe sepsis known as overwhelming post-splenectomy infection (OPSI), which has a very high mortality rate.

Encapsulated bacteria form a major proportion of the invading organisms, of which the most common is Streptococcus pneumoniae. OPSI is a medical emergency that requires prompt diagnosis (with blood cultures and sensitivity, blood glucose levels, renal function tests, and electrolyte levels) and management with fluid resuscitation along with immediate administration of empirical antimicrobials. OPSI can be prevented by educating patients, vaccination, and antibiotic prophylaxis. This article summarizes the anatomy and physiology of the spleen and highlights its important functions. It primarily focuses on the pathophysiology of OPSI, its current management, and prevention strategies.
\end{abstract}

Received 02/03/2020

Review began 02/03/2020 Review ended 02/04/2020 Published 02/06/2020

\section{(c) Copyright 2020}

Tahir et al. This is an open access article distributed under the terms of the Creative Commons Attribution License CC-BY 4.0., which permits unrestricted use, distribution, and reproduction in any medium, provided the original author and source are credited.
Categories: General Surgery, Infectious Disease, Public Health

Keywords: splenectomy, spleen, overwhelming post-splenectomy infection, opsi, sepsis, vaccination, asplenia, infection

\section{Introduction And Background}

The spleen, a lymphoid aggregate, lies behind ribs 9-10 in the left hypochondriac region of the abdominal cavity where a part of it lies in the epigastric region. Thus, the largest organ of the lymphatic system is situated between the fundus of the stomach and the diaphragm. Being a highly vascular structure, the spleen appears spongy and reddish-purple in color. An adult human spleen is roughly the size of a clenched fist, although its size and weight vary, measuring about $10-12 \mathrm{~cm}$ (3.9-4.7 inch) vertically in the longest dimension while weighing $150-200$ grams on average $[1,2]$. It is the only lymphoid organ that lies directly in the path of the blood circulation. Due to its heterogeneous structure, the spleen performs a variety of immunological and hematological functions. It plays a key role in both the innate and adaptive immune systems, thereby protecting the body from invading organisms [3].

Therapeutic splenectomy for malarial splenomegaly was performed as early as 1549 by Adriano Zaccaria. The first partial splenectomy dates back to 1590 and was performed by Franciscus Rosetti for war-related traumatized spleen [4]. In 1826, Quittembaum performed splenectomy in a 22-year-old woman for the removal of a large splenic tumor. In 1893, Jaboulay coined the term “exosplenopexy” to describe the partial removal of the spleen while attaching it to the external wound edges. The exterior part of the spleen would then eventually undergo atrophy. In comparison, Pallavecchio destroyed the exterior part of the spleen thermally instead of waiting for spontaneous regression and, hence, named the process "exosplenolisi" [5].

In 1911, Emil T Kocher stated that splenic injuries required the removal of the whole organ, and it had no adverse effects [4]. This led to the belief that splenectomy could be performed in all cases. However, in 1919, Morris and Bullock established that partial or complete removal of the spleen was associated with an increased risk of infections in splenectomized individuals [3]. This finding was further supported by King and Shumacker in 1952 when they reported severe sepsis in five children who had undergone splenectomy for congenital hemolytic anemia [6]. In 1962, Horan and Colebatch published a detailed review that revealed that incidences of fatal infection in asplenic children were 10 times higher (5.6-8.7\%) than in the control population (0.7\%) [7]. Thus, the removal of the spleen makes patients susceptible to a variety of different infections caused by organisms such as Staphylococcus aureus, Haemophilus influenzae, Streptococcus pneumoniae, and malarial parasites. Sepsis in asplenic patients is more likely to be caused by encapsulated organisms as they are more resilient to phagocytosis. The most dreadful complication of splenectomy is overwhelming post-splenectomy infection (OPSI), which is associated with significant morbidity and mortality rates. 
Scientific community and physicians are using a multidimensional approach to tackle the problem of OPSI. This approach involves patient education, the use of preoperative as well as postoperative vaccinations against specific organisms, prophylaxis with antibiotics, and the maintenance of a spleen registry following splenectomy. We aimed to review the existing literature on the topic and gather a comprehensive picture of splenectomy and the associated sequelae along with its management and preventive strategies.

\section{Review}

\section{The Spleen}

Embryology

During the sixth week of fetal development, the spleen develops from the left layer of dorsal mesogastrium in the cephalic part into multiple nodules that later fuse to form a lobulated spleen. In an adult spleen, notching of the superior border shows evidence of its multiple origins. During intrauterine life, the rotation of the stomach causes fusion of the left mesogastric surface with the peritoneum above the left kidney and, consequently, dorsal attachment of the lienorenal ligament. Cells required for the hematopoietic function of the spleen are supplied by the yolk sac and dorsal aorta. By the second trimester, the spleen is able to generate red and white blood cells into the blood circulation.

\section{Location}

The spleen lies posterior to the stomach and anterior to the left hemidiaphragm in the left hypochondriac region of the abdominal cavity, relatively below the left costal margin. It rests on the left colic (splenic) flexure, facing the left kidney and pancreatic tail medially and the diaphragm superiorly. Although it can descend up to pubic symphysis in certain disorders, a healthy normal spleen is usually not palpable in most individuals as it normally does not extend beyond the rib arch.

\section{Gross Anatomy}

The spleen is encased in a weak fibroelastic connective tissue capsule that offers protection and expansion. The capsule further subdivides into smaller internal sections known as lobules. Being an intraperitoneal organ, all surfaces of the spleen are enveloped in the visceral peritoneum, except the hilum, which incorporates nerves, splenic vessels, and ligamentous attachments. The spleen has two surfaces: the diaphragmatic or lateral surface (smooth and convex) and the visceral or medial surface (concave and irregular with several imprints). The diaphragmatic surface shows imprints from ribs 9-11, while the visceral surface shows imprints from left colic flexure (colic area), stomach (gastric area), and left kidney (renal area). The spleen has three borders: superior (which bounds the gastric area), inferior (which bounds the renal area), and anterior (which bounds the colic area). The splenic hilum is found inferomedial to the gastric area. The pancreatic tail leaves an impression between the hilum and colic area. Three ligaments originating from adjacent viscera connect with the spleen. Out of them, two ligaments approach the splenic hilum as they are traversed by the transmitted vascular supply of the spleen. These ligaments include the gastrosplenic ligament (which connects splenic hilum with greater gastric curvature) and the splenorenal ligament (which bridges splenic hilum with left kidney). The latter transmits splenic artery and vein whereas the former contains short gastric vessels and left gastroepiploic arteries and veins. Lastly, the spleen is supported by the phrenicocolic ligament, which takes its origin from the colon and is regarded as sustentaculum lienis.

Microscopic Anatomy and Functions of the Spleen

Knowledge of the microscopic anatomy of the spleen is vital for the understanding of its functions. The dense irregular connective tissue of the capsule gives numerous septa called trabeculae that extend into the parenchyma of the spleen. Myoepithelial cells are found in the capsule as well as in the trabeculae, which contract to pump stored blood into the circulatory system whenever the body is in need, i.e., during intense physical activity or severe hemorrhage. The parenchyma of the spleen (pulp) contains two different types of tissues, termed white and red pulp, each with unique functions. The white pulp, constituting $25 \%$ of the total splenic volume, is primarily lymphocytic. It is mainly composed of periarteriolar lymphoid sheaths (PALS; T-cell dominant) and lymphatic nodules (B-cells). The remaining $75 \%$ of the splenic volume is occupied by the red pulp, which incorporates splenic venous sinuses, cords (of Billroth), and perisinusoidal macrophages. Separating white and red pulp is the marginal zone that filters pathogens out of the blood and presents them to the lymphocytes residing in white pulp [8]. A schematic diagram of the microstructure of the spleen is shown in Figure 1. Table 1 summarizes the neurovascular supply and lymphatic drainage of the spleen. Table 2 enlists various functions executed by a healthy human spleen. 


\section{Cureus}

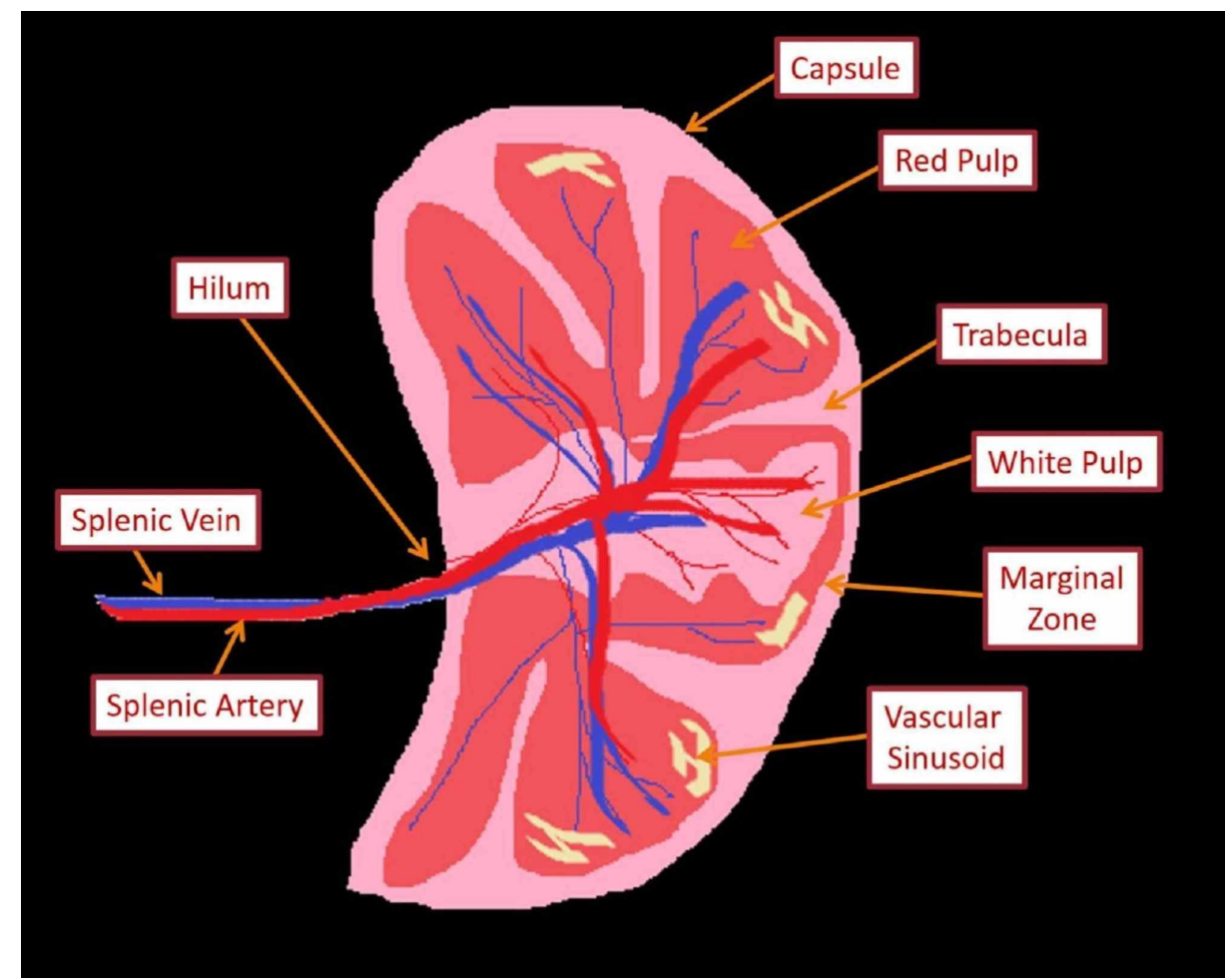

FIGURE 1: Schematic diagram of microstructure of the spleen

\begin{tabular}{l|l}
$\begin{array}{l}\text { Characteristics } \\
\text { Arterial supply }\end{array}$ & $\begin{array}{l}\text { Structures involved } \\
\text { spleen }\end{array}$ \\
$\begin{array}{l}\text { Venous drainage } \\
\text { Innervation }\end{array}$ & Splenic vein, which later joins superior mesenteric vein to give rise to the portal vein \\
$\begin{array}{l}\text { Lymphatic } \\
\text { drainage }\end{array}$ & Celiac lymph node (receives lymph from pancreaticosplenic lymph nodes
\end{tabular}

TABLE 1: Neurovascular supply and lymphatic drainage of the spleen 


\section{Cureus}

Immunological functions

Red pulp macrophages decontaminate the blood from pathogens

Marginal zone macrophages get rid of the circulating microorganisms and cellular debris

Tingible body macrophages discard B-cell debris in the germinal center of the follicle

Dendritic cells, natural killer cells, and monocytes induce T lymphocyte formation

Splenic B cells produce antigen-specific antibodies and augment cytotoxic $\mathrm{T}$ cell response

IgM memory B cells produce IgM to promote the clearance of polysaccharide-encapsulated bacteria

Production of immune mediators such as complement, opsonins, properdin, and tufts, which instigate phagocytosis

\section{Hematological functions}

Removal of unwanted intra-erythrocytic inclusions, i.e., Howell-Jolly bodies and erythrocyte pits

Pooling of platelets along with sequestration of erythrocytes, granulocytes, plasmablasts, and plasma cells

Phagocytosis of defective or old erythrocytes in the blood circulation

Hematopoiesis during fetal life

Extramedullary hematopoiesis (if required)

Storage of iron

TABLE 2: Functions of the spleen

IgM: immunoglobulin M

Changes in Splenic Function with Advancing Age

Inadequate defense mechanism against encapsulated bacteria during the early and later years of life is a consequence of a natural process involving splenic cellular maturation, which occurs during the first two decades of life. The concentration of follicles diminishes as individual ages, particularly after the third decade, until they are atrophic by the eighth decade of life. This indicates that the immunological function of the spleen deteriorates with age [9].

\section{Splenectomy}

Splenectomy, or the surgical removal of the spleen, is usually considered a life-saving procedure in traumatized individuals, certain hematological disorders, malignant conditions, and for the sake of diagnostic purposes [10]. Globally, the incidence of splenectomy is nearly 6.4-7.1 per 100,000 people per annum, with trauma (25\%) and hematological disorders (25\%) being the most common culprits [5]. Abdominal trauma leading to the rupture of the spleen with internal bleeding and hemodynamic instability usually ends up with splenectomy [11]. But, due to the advent of alternative approaches, splenectomy in trauma settings is on the decline. Hematological conditions requiring splenectomy include idiopathic thrombocytopenic purpura (immune thrombocytopenia; ITP), sickle cell disease, thalassemia, and hereditary spherocytosis (HS) $[6,12,13]$. Table 3 lays out the main indications and contraindications of splenectomy. 


\section{Cureus}

\begin{tabular}{|c|c|c|c|}
\hline Absolute indications for splenectomy & $\begin{array}{l}\text { Relative indications } \\
\text { for splenectomy }\end{array}$ & $\begin{array}{l}\text { Absolute contraindications for } \\
\text { splenectomy }\end{array}$ & $\begin{array}{l}\text { Relative contraindications for } \\
\text { splenectomy (laparoscopic } \\
\text { approach) }\end{array}$ \\
\hline $\begin{array}{l}\text { Splenic trauma, i.e., splenic rupture either } \\
\text { spontaneous (tropical splenomegaly) or delayed } \\
\text { (subcapsular hematoma) }\end{array}$ & $\begin{array}{l}\text { Congenital or acquired } \\
\text { hemolytic anemia }\end{array}$ & Uncorrectable coagulopathy & $\begin{array}{l}\text { Active hemorrhage with } \\
\text { hemodynamic instability }\end{array}$ \\
\hline HS & Thalassemia & $\begin{array}{l}\text { Severe cardiovascular disease } \\
\text { making the patient unfit for } \\
\text { general anesthesia }\end{array}$ & Non-platelet coagulopathy \\
\hline Splenic abscess (TB infection) & $\begin{array}{l}\text { Acute, chronic } \\
\text { myeloid or chronic } \\
\text { lymphatic leukemia }\end{array}$ & Cirrhosis with portal hypertension & $\begin{array}{l}\text { Contraindications to } \\
\text { pneumoperitoneum }\end{array}$ \\
\hline Splenic cyst & $\begin{array}{l}\text { Lymphoma } \\
\text { (Hodgkin's) }\end{array}$ & & Splenomegaly \\
\hline $\begin{array}{l}\text { As part of radical surgical removal of locally } \\
\text { advanced gastric carcinoma, pancreatic } \\
\text { carcinoma }\end{array}$ & $\begin{array}{l}\text { Polycythaemia vera } \\
\text { and myelofibrosis }\end{array}$ & & Pregnancy \\
\hline Angioma & Acute or chronic ITP & & $\begin{array}{l}\text { Extensive previous upper } \\
\text { abdominal surgery }\end{array}$ \\
\hline Primary splenic malignancy (rare) & $\begin{array}{l}\text { Parasitic infestation, } \\
\text { malaria, and Felty's } \\
\text { syndrome }\end{array}$ & & \\
\hline Aneurysm of splenic artery & $\begin{array}{l}\text { Angioma, cysts, and } \\
\text { metastases }\end{array}$ & & \\
\hline \multirow[t]{3}{*}{$\begin{array}{l}\text { Bleeding esophageal varices secondary to splenic } \\
\text { vein thrombosis }\end{array}$} & $\begin{array}{l}\text { Tropical or non- } \\
\text { tropical splenomegaly }\end{array}$ & & \\
\hline & $\begin{array}{l}\text { Intrahepatic or } \\
\text { extrahepatic portal } \\
\text { hypertension }\end{array}$ & & \\
\hline & $\begin{array}{l}\text { Amyloidosis and } \\
\text { Gaucher's disease }\end{array}$ & & \\
\hline
\end{tabular}

\section{TABLE 3: Indications and contraindications for splenectomy}

HS: hereditary spherocytosis; TB: tuberculosis; ITP: idiopathic thrombocytopenic purpura

Infections Following Splenectomy

Although the presence of spleen is not imperative for the survival of human beings, its removal still has consequences. Until 1952, when King and Schumacher revealed the risk of OPSI, the spleen was considered an unnecessary organ and a spleenless existence was thought to be quite safe [5]. Nowadays, it is clearly evident that splenectomy induces an increased risk of infection and thromboembolism [14]. The factors responsible for an increased incidence of infection and propensity for severity following a splenectomy include insufficient opsonizing filter function of the spleen, delayed and impaired production of immunoglobulin (Ig), lack of splenic macrophages, and minimal tufts production [5]. Nevertheless, the complement system remains unchanged as levels of serum complement components $\mathrm{C} 3$, $\mathrm{C} 4$, and transferrin do not fluctuate [15]. Furthermore, the abolishment of the cholinergic anti-inflammatory pathway ensuing splenectomy may contribute to the increased propensity for OPSI, although a direct association has not been established yet [5].

Splenectomy can be immediately followed by reactive thrombocytosis and leukocytosis. The former usually resolves within 6-12 months, whereas the latter may persist for many years following the removal of the spleen [16]. Leukocytosis is predominantly granulocyte-driven, as elevated levels of neutrophils are usually appreciated after splenectomy [17]. Along with the quality of erythrocytes, the proportions of lymphocyte cohorts are also altered. Although the total B lymphocytes remain intact, a significant fall in the levels of memory B cells and switched B cell proportions are usually encountered 150 days post-splenectomy [18]. 
This acts as a particular predisposition to infections caused by polysaccharide-encapsulated bacteria and is responsible for a diminished immunological response to polysaccharide vaccines $[19,20]$. These hematological and immunological amendments predispose splenectomized individuals to various infections. Following splenectomy, individuals end up with an elevated risk of infection, mainly from encapsulated Gram-negative pathogens, i.e., Capnocytophaga canimorsus and Bordetella holmesii [21, 22], and intraerythrocytic parasites, i.e., intraerythrocytic malaria and Babesia parasites [23,24].

\section{Overwhelming post-splenectomy infection}

The major long-term complication of splenectomy is OPSI, also known as post-splenectomy sepsis syndrome, which is defined as a generalized non-specific flu-like prodrome followed by rapid deterioration to full-blown fulminant septic shock within 24-48 hours of the onset [9]. Although there is no specific diagnostic criterion for OPSI, prompt identification followed by proper management can prevent further deterioration and fatality [25]. The prevalence of OPSI following splenectomy is $0.1-0.5 \%$, with a mortality rate of up to $50 \%[26]$.

The period of highest risk for infections is during the first 3 years post-splenectomy; however, the risk remains elevated throughout an individual's lifespan, indicated by the reported occurrence of cases of fulminant infection 20 years after splenectomy [6]. Children under 2-5 years of age, those who have had splenectomy post-trauma, individuals splenectomized for hematological malignancy or malignant conditions, and immunosuppressed or immunodeficient individuals (e.g., HIV-infected) are at a greater risk for OPSI $[5,27]$.

In the late 1990s and early 2000s, pneumococcus was considered the predominant cause of infection postsplenectomy (57-87\%). However, recent studies suggest that Neisseria meningitidis and Haemophilus influenzae (type b) are also common etiologic agents $[28,29]$. Less common organisms include Gram-negative bacteria such as Pseudomonas aeruginosa, Capnocytophaga canimorsus, Bartonella spp., and Babesia spp. [30]. Pneumococcal infection is by far the most common with an associated mortality rate of up to $60 \%[20,24]$. However, reports from Denmark have shown Escherichia coli (E. coli) to be the most prevalent in postsplenectomy bacteremia; but it may be a regional phenomenon [25]. This might relate to the concomitant administration of penicillin and pneumococcal vaccine in splenectomized individuals [31].

OPSI is a medical emergency as rapid cardiovascular collapse and death have been reported to occur within 12-24 hours of the onset of symptoms [29]. It starts as a prodrome with fever, chills, myalgia, headache, vomiting, and abdominal pain, progressively leading to coma, septic shock, and disseminated intravascular coagulation (DIC) [32]. Polysaccharide-specific antibodies activate the complement pathway, thereby promoting the deposition of complement fragments directly on to the capsule and, hence, thrombotic vascular occlusion. This might suggest an association between OPSI and DIC [33]. An indication for the administration of corticosteroids in OPSI is a frequent finding of bilateral adrenal hemorrhage, mimicking Waterhouse-Friderichsen syndrome (WFS) [29].

Initially, the condition may be difficult to diagnose. However, any splenectomized individual with symptoms like fever, chills, diarrhea, and vomiting should be assessed for OPSI. Individuals suffering from severe sepsis or septic shock must be evaluated in accordance with the international guidelines [34] along with prompt administration of empiric, broad-spectrum antibiotics. At least two sets of blood cultures should be collected prior to antibiotic therapy for the identification of the offending pathogen. Laboratory investigations should cover blood glucose level, serum lactate concentration, and electrolytes with hematological and renal profiles. A peripheral blood smear or a buffy coat for the presence of bacteria and a blood film for the evaluation of Howell-Jolly bodies should be urgently ordered while awaiting the results of blood cultures. Evidence shows that the instantaneous administration of empiric antimicrobial therapy is associated with an increased survival rate [35]. Additionally, aggressive fluid therapy and constant monitoring also play an imperative role in the management of OPSI. In order to diminish the levels of inflammatory mediators and enhance the hemodynamic stability in splenectomized individuals with pneumococcal sepsis, it has been proved beneficial to consider blood purification techniques with adjunctive adsorbent therapy [36,37].

\section{Prevention of post-splenectomy infection}

Despite adequate treatment, the mortality rate pertaining to OPSI remains high. This highlights the importance of implementing preventive strategies in the effective management of splenectomized individuals. The British Committee for Standards in Haematology has set guidelines for the prevention and treatment of infections in the asplenic or hyposplenic population, which can be divided roughly into three categories: patient education, vaccination, and prophylaxis with antibiotics [28].

\section{Patient Education}

A vast majority (85\%) of splenectomized individuals are not aware of their increased susceptibility to infectious diseases and the need to take relevant health precautions [38]. Inadequate information and lack of sufficient education seem to be the major culprit behind this lack of awareness [36,39]. Patients and their family members should be educated regarding their asplenic status in both written and electronic form [35]. 


\section{Cureus}

Table 4 describes the information that must be provided to asplenic individuals.

\section{Summary of patient education details}

Splenectomy carries a lifelong increased risk of infections

Initial symptoms of OPSI include high-grade fever $\left(>38^{\circ} \mathrm{C}\right)$, chills, myalgia, headache, vomiting, and abdominal pain

Please notify your healthcare workers about your asplenic status

Seek immediate medical attention on events like animal bites and scratches

Consider seeking medical advice prior to traveling, especially before visiting a malaria-endemic area

Always carry antibiotic supplies with you (may find helpful in case of sudden illness)

Never forget to carry a medical alert

If available, must consider registering in a "spleen registry system"

\section{TABLE 4: Information and directions for splenectomized patients}

OPSI: overwhelming post-splenectomy infection

Vaccination

All asplenic individuals must receive pneumococcal, Haemophilus influenza type b (Hib), meningococcal, and annual influenza vaccinations [35]. These vaccines are mainly recommended for infection prophylaxis due to their clinical effectiveness. For instance, immunization seems to be partially responsible for reducing the rate of post-splenectomy sepsis $[40,41]$. Keeping in view the Centers for Disease Control and Prevention (CDC)-recommended adult immunization schedule, Table 5 details vaccination guidelines for splenectomized individuals [42]. 


\section{Cureus}

\begin{tabular}{|c|c|c|c|}
\hline Recommended vaccine & $\begin{array}{l}\text { Dose of the } \\
\text { vaccine }\end{array}$ & $\begin{array}{l}\text { Route of } \\
\text { administration }\end{array}$ & Time of administration \\
\hline \multicolumn{4}{|l|}{ In-hospital protocol } \\
\hline $\begin{array}{l}\text { Pneumococcal 13-valent conjugate (PCV13: } \\
\text { Prevnar 13) }\end{array}$ & $0.5 \mathrm{~mL}$ & IM & $\begin{array}{l}\text { On the day of discharge or day } 14 \text {, whichever } \\
\text { comes first }\end{array}$ \\
\hline $\begin{array}{l}\text { Haemophilus influenza type b vaccine (Hib: } \\
\text { ActHIB) }\end{array}$ & $0.5 \mathrm{~mL}$ & IM & $\begin{array}{l}\text { On the day of discharge or day } 14 \text {, whichever } \\
\text { comes first }\end{array}$ \\
\hline Meningococcal vaccine (Menactra) & $0.5 \mathrm{~mL}$ & $\mathrm{IM}$ & $\begin{array}{l}\text { On the day of discharge or day } 14 \text {, whichever } \\
\text { comes first }\end{array}$ \\
\hline Meningococcal serogroup B (Bexsero) & $0.5 \mathrm{~mL}$ & IM & $\begin{array}{l}\text { On the day of discharge or day } 14 \text {, whichever } \\
\text { comes first }\end{array}$ \\
\hline \multicolumn{4}{|l|}{ Short-term follow-up } \\
\hline $\begin{array}{l}\text { Pneumococcal polysaccharide (PPSV23: } \\
\text { Pneumovax 23) }\end{array}$ & $0.5 \mathrm{~mL}$ & IM & Two months after the initial vaccination \\
\hline Meningococcal vaccine & $0.5 \mathrm{~mL}$ & IM & Two months after the initial vaccination \\
\hline Meningococcal serogroup B & $0.5 \mathrm{~mL}$ & IM & Two months after the initial vaccination \\
\hline \multicolumn{4}{|l|}{ Long-term follow-up } \\
\hline Pneumococcal polysaccharide & $0.5 \mathrm{~mL}$ & IM & 5 years after the first dose \\
\hline Meningococcal vaccine & $0.5 \mathrm{~mL}$ & IM & Every 5 years \\
\hline Seasonal influenza vaccine & - & - & Annually \\
\hline
\end{tabular}

\section{TABLE 5: CDC-recommended adult immunization schedule after splenectomy}

CDC: Centers for Disease Control and Prevention; IM: intramuscular

Antibiotic Prophylaxis

In the 1980s, two controlled trials evaluated the effectiveness of prophylactic penicillin in the pediatric population with sickle cell disease where rates of infection with Streptococcus pneumoniae declined [43,44]. Oral penicillins, normally the prophylactic drugs of choice, are now considered less effective due to the emission of bacterial resistance [45]. In contrast, a broader spectrum of activity has been suggested for amoxicillin-clavulanic acid, trimethoprim-sulfamethoxazole (TMP/SMX), or cefuroxime [46]. Initially, after splenectomy, most guidelines recommend a daily regimen of antibiotic therapy, while the need for lifelong consumption can be decided after evaluating the risk of infection [5]. Table 6 enlists individuals who are considered high-risk populations who should be administered lifelong prophylactic antibiotic therapy as recommended by the British guidelines [35]. 


\section{Cureus}

High-risk population

Children younger than 16 years of age

Adults older than 50 years of age

Individuals with a past history of invasive pneumococcal infection

Individuals splenectomized for hematologic malignant diseases, malignant neoplasms, and thalassemia

Individuals in the first year post-splenectomy, irrespective of the cause

Patients with sickle cell anemia

Individuals with a poor response to PPV-23

TABLE 6: High-risk population who should be administered lifelong antibiotic prophylaxis after splenectomy

PPV: pneumococcal polysaccharide vaccine

Benefits of Having a Spleen Registry

In a cross-sectional survey, Wang J. et al. reported higher rates of adherence to current post-splenectomy guidelines among patients who had been registered in the Victorian Spleen Registry. They also reported reduced incidences of infections among this cohort [47]. In another retrospective cohort study, Arnott A. et al. concluded that systemic, long-term approaches can significantly minimize the risk of infection with encapsulated pathogens among splenectomized individuals [48]. According to Premawardena C et al., major benefits of the registry were not related to the knowledge but in the delivery of the recommended vaccines and the use of a medical alert card [49].

\section{Conclusions}

Therapeutic removal of the spleen is currently widely carried out in hematological and oncological disorders. The removal of the spleen leaves the body defenseless against many infections as the body's ability to opsonize bacteria is weakened. The individual becomes susceptible to a variety of respiratory, urinary, and meningeal infections. Seeding of bacteria from infection sites can lead to bacteremia and a severe case of sepsis knows as OPSI. Due to its rapid progression and high mortality rate, OPSI is considered a serious medical emergency. The timely identification of OPSI, its immediate management, and vigilant care of splenectomized patients provides them with a better chance of survival.

In order to reduce post-splenectomy infections, patient education, vaccination, and prophylactic antibiotics are of prime importance. Splenectomized patients who are aware of the dangers that infections could cause are likely to be more careful and adherent to precautionary measures. All asplenic individuals must receive pneumococcal, Haemophilus influenza type b (Hib), meningococcal, and annual influenza vaccinations along with prophylactic antibiotics (amoxicillin-clavulanic acid, TMP/SMX, or cefuroxime) as these measures have been found effective in decreasing the incidence of post-splenectomy infections. The formation of a spleen registry has also been found beneficial in reducing infection rates. Further research is needed to improve the current prevention and treatment strategies for OPSI and thereby improve the quality of life of high-risk (splenectomized or asplenic) patients.

\section{Additional Information}

\section{Disclosures}

Conflicts of interest: In compliance with the ICMJE uniform disclosure form, all authors declare the following: Payment/services info: All authors have declared that no financial support was received from any organization for the submitted work. Financial relationships: All authors have declared that they have no financial relationships at present or within the previous three years with any organizations that might have an interest in the submitted work. Other relationships: All authors have declared that there are no other relationships or activities that could appear to have influenced the submitted work.

\section{References}

1. Steiniger BS, Wilhelmi V, Berthold M, Guthe M, Lobachev O: Locating human splenic capillary sheaths in virtual reality. Sci Rep. 2018, 8:15720. Accessed: January 26, 2020: https://www.nature.com/articles/s41598018-34105-3. 10.1038/s41598-018-34105-3 
2. Lung K, Lui F: Anatomy, Abdomen and Pelvis, Arteries. Miller R, Sneden T, Hughes E, Beatty B, Rubio G (ed): StatPearls Publishing, Treasure Island, Florida; 2018.

3. Morris DH, Bullock FD: The importance of the spleen in resistance to infection . Ann Surg. 1919, 70:513-521. 10.1097/00000658-191911000-00001

4. Dionigi R, Boni L, Rausei S, Rovera F, Dionigi G: History of splenectomy. Int J Surg. 2013, 11:S42-S43. 10.1016/S1743-9191(13)60013-8

5. Morgenstern L: A history of splenectomy. Surgical Diseases of the Spleen. Hiatt JR, Phillips EH, Morgenstern L (ed): Springer Berlin Heidelberg, Heidelberg, Germany; 1997. 1:3-14. 10.1007/978-3-64260574-1_1

6. King H, Shumacker HB Jr: Splenic studies: 1 . susceptibility to infection after splenectomy performed in infancy. Ann Surg. 1952, 136:239-242. 10.1097/00000658-195208000-00006

7. Horan M, Colebatch JH: Relation between splenectomy and subsequent infection. A clinical study . Arch Dis Child. 1962, 37:398-414. 10.1136/adc.37.194.398

8. Bajwa SA, Kasi A: Anatomy, Abdomen and Pelvis, Accessory spleen. Miller R, Sneden T, Hughes E, Beatty B, Rubio G (ed): StatPearls Publishing, Treasure Island, Florida; 2018.

9. Lizamma A, Rajan ML, Xavier B, Jacob P, Rani KD, Lakshmi G: Microscopic study of human spleen in different age groups. Int J Res Med Sci. 2015, 3:1701-1706. 10.18203/2320-6012.ijrms20150255

10. Luu S, Spelman D, Woolley IJ: Post-splenectomy sepsis: preventative strategies, challenges, and solutions . Infect Drug Resist. 2019, 12:2839-2851. Accessed: February 5, 2020:

https://www.ncbi.nlm.nih.gov/pmc/articles/PMC6748314/. 10.2147/IDR.S179902

11. Dendle C, Sundararajan V, Spelman T, Jolley D, Woolley I: Splenectomy sequelae: an analysis of infectious outcomes among adults in Victoria. Med J Aust. 2012, 196:582-586. 10.5694/mja11.10909

12. Chaturvedi S, Arnold DM, McCrae KR: Splenectomy for immune thrombocytopenia: down but not out . Blood. 2018, 131:1172-1182. 10.1182/blood-2017-09-742353

13. Sandusky WR, Leavell BS, Benjamin BI: Splenectomy: indications and results in hematologic disorders . Ann Surg. 1964, 159:695-709. 10.1097/00000658-196405000-00007

14. Kristinsson SY, Gridley G, Hoover RN, Check D, Landgren O: Long-term risks after splenectomy among 8,149 cancer-free American veterans: a cohort study with up to 27 years follow-up. Haematologica. 2014, 99:392398. 10.3324/haematol.2013.092460

15. el Akkad H, Sass W, Colberg A, Knippert A, Seifert J: New arguments to explain the high infection rate in posttraumatic spleenless patients. Zentralbl Chir. 1997, 122:909-913.

16. Rab MAE, Meerveld-Eggink A, van Velzen-Blad H, van Loon D, Rijkers GT, de Weerdt O: Persistent changes in circulating white blood cell populations after splenectomy. Int J Hematol. 2018, 107:157-165. 10.1007/s12185-017-2335-9

17. Lipson RL, Bayrd ED, Watkins CH: The postsplenectomy blood picture. Am J Clin Pathol. 1959, 32:526-532. 10.1093/ajcp/32.6.526

18. Cameron PU, Jones PA, Gorniak M, et al.: Splenectomy associated changes in IgM memory B cells in an adult spleen registry cohort. PLoS One. 2011, 6:e23164. Accessed: January 26, 2020: https://www.ncbi.nlm.nih.gov/pubmed/21829713. 10.1371/journal.pone.0023164

19. Amlot PL, Grennan D, Humphrey JH: Splenic dependence of the antibody response to thymus-independent (TI-2) antigens. Eur J Immunol. 1985, 15:508-512. 10.1002/eji.1830150516

20. Zandvoort A, Timens W: The dual function of the splenic marginal zone: essential for initiation of anti-TI-2 responses but also vital in the general first-line defense against blood-borne antigens. Clin Exp Immunol. 2002, 130:4-11. 10.1046/j.1365-2249.2002.01953.x

21. Lion C, Escande F, Burdin JC: Capnocytophaga canimorsus infections in human: review of the literature and cases report. Eur J Epidemiol. 1996, 12:521-533. 10.1007/bf00144007

22. Shepard CW, Daneshvar MI, Kaiser RM, et al.: Bordetella holmesii bacteremia: a newly recognized clinical entity among asplenic patients. Clin Infect Dis. 2004, 38:799-804. 10.1086/381888

23. Chotivanich K, Udomsangpetch R, McGready R, et al.: Central role of the spleen in malaria parasite clearance. J Infect Dis. 2002, 185:1538-1541. 10.1086/340213

24. Rosner F, Zarrabi MH, Benach JL, Habicht GS: Babesiosis in splenectomized adults: review of 22 reported cases. Am J Med. 1984, 76:696-701. 10.1016/0002-9343(84)90298-5

25. Brigden ML: Overwhelming postsplenectomy infection still a problem. West J Med. 1992, 157:440-443.

26. Sarangi J, Coleby M, Trivella M, Reilly S: Prevention of post splenectomy sepsis: a population based approach. J Public Health Med. 1997, 19:208-212. 10.1093/oxfordjournals.pubmed.a024611

27. Weledji EP: Benefits and risks of splenectomy. Int J Surg. 2014, 12:113-119. 10.1016/j.ijsu.2013.11.017

28. Davies JM, Lewis MP, Wimperis J, Rafi I, Ladhani S, Bolton-Maggs PH: Review of guidelines for the prevention and treatment of infection in patients with an absent or dysfunctional spleen: prepared on behalf of the British Committee for Standards in Haematology by a working party of the Haemato-Oncology task force. Br J Haematol. 2011, 155:308-317. 10.1111/j.1365-2141.2011.08843.x

29. Francke EL, Neu HC: Post splenectomy infection. Surg Clin North Am. 1981, 61:135-155. 10.1016/s00396109(16)42339-X

30. Taniguchi LU, Correia MD, Zampieri FG: Overwhelming post-splenectomy infection: narrative review of the literature. Surg Infect (Larchmt). 2014, 15:686-693. 10.1089/sur.2013.051

31. Ejstrud P, Kristensen B, Hansen JB, Madsen KM, Schønheyder HC, Sørensen HT: Risk and patterns of bacteraemia after splenectomy: a population-based study. Scand J Infect Dis. 2000, 32:521-525. 10.1080/003655400458811

32. Gopal V, Bisno AL: Fulminant pneumococcal infections in "normal” asplenic hosts. Arch Intern Med. 1977, 137:1526-1530. 10.1001/archinte.1977.03630230022009

33. Saeland E, Vidarsson G, Leusen JHW, et al.: Central role of complement in passive protection by human IgG1 and IgG2 anti-pneumococcal antibodies in mice. J Immunol. 2003, 170:6158-6164. 10.4049/jimmunol.170.12.6158

34. Dellinger RP, Levy MM, Rhodes A, et al.: Surviving sepsis campaign: international guidelines for management of severe sepsis and septic shock, 2012. Intensive Care Med. 2013, 39:165-228. 
10.1007/s00134-012-2769-8

35. Kumar A, Roberts D, Wood KE, et al.: Duration of hypotension before initiation of effective antimicrobial therapy is the critical determinant of survival in human septic shock. Crit Care Med. 2006, 34:1589-1596. 10.1097/01.CCM.0000217961.75225.E9

36. Leonardis F, De Angelis V, Frisardi F, et al.: Effect of hemoadsorption for cytokine removal in pneumococcal and meningococcal sepsis. Case Rep Crit Care. 2018, 2018:1205613. 10.1155/2018/1205613

37. Sinkovic A, Kit B, Markota A: Successful use of combined blood purification techniques in splenectomised patient with septic shock in streptococcus pneumoniae infection - a case report. BMC Infect Dis. 2018, 18:433. Accessed: January 26, 2020: https://www.ncbi.nlm.nih.gov/pubmed/30157806. 10.1186/s12879-0183327-y

38. White KS, Covington D, Churchill P, Maxwell JG, Norman KS, Clancy TV: Patient awareness of health precautions after splenectomy. Am J Infect Control. 1991, 19:36-41. 10.1016/0196-6553(91)90158-9

39. Lammers AJ, Veninga D, Lombarts MJ, Hoekstra JB, Speelman P: Management of post-splenectomy patients in the Netherlands. Eur J Clin Microbiol Infect Dis. 2010, 29:399-405. 10.1007/s10096-009-0870-X

40. Brigden ML, Pattullo A, Brown G: Pneumococcal vaccine administration associated with splenectomy: the need for improved education, documentation, and the use of a practical checklist. Am J Hematol. 2000, 65:25-29. 10.1002/1096-8652(200009)65:1<25::aid-ajh4>3.0.c0;2-8

41. Mourtzoukou EG, Pappas G, Peppas G, Falagas ME: Vaccination of asplenic or hyposplenic adults. Br J Surg. 2008, 95:273-280. 10.1002/bjs.6106

42. Centers for Disease Control and Prevention - recommended adult immunization schedule for ages 19 years or older, United States, 2019. (2019). Accessed: January 27, 2020: http://www.cdc.gov/vaccines/schedules/hcp/adult.html.

43. John AB, Ramlal A, Jackson H, Maude GH, Sharma AW, Serjeant GR: Prevention of pneumococcal infection in children with homozygous sickle cell disease. Br Med J (Clin Res Ed). 1984, 288:1567-1570. 10.1136/bmj.288.6430.1567

44. Gaston MH, Verter JI, Woods G, et al.: Prophylaxis with oral penicillin in children with sickle cell anemia: a randomized trial. N Engl J Med. 1986, 314:1593-1599. 10.1056/NEJM198606193142501

45. Rose MA, Schubert R, Strnad N, Zielen S: Priming of immunological memory by pneumococcal conjugate vaccine in children unresponsive to 23 -valent polysaccharide pneumococcal vaccine. Clin Diagn Lab Immunol. 2005, 12:1216-1222. 10.1128/CDLI.12.10.1216-1222.2005

46. Brigden ML: Detection, education and management of the asplenic or hyposplenic patient. Am Fam Physician. 2001, 63:499-508.

47. Wang J, Jones P, Cheng AC, Leder K: Adherence to infection prevention measures in a statewide spleen registry. Med J Aust. 2014, 200:538-540. 10.5694/mja13.10630

48. Arnott A, Jones P, Franklin LJ, Spelman DW, Leder K, Cheng AC: A registry for patients with asplenia/hyposplenism reduces the risk of infections with encapsulated organisms. Clin Infect Dis. 2018, 67:557-561. 10.1093/cid/ciy141

49. Premawardena C, Bowden D, Kaplan Z, Dendle C, Woolley IJ: Understanding of the significance and health implications of asplenia in a cohort of patients with haemaglobinopathy: possible benefits of a spleen registry. Hematology. 2018, 23:526-530. 10.1080/10245332.2017.1414910 